\title{
Leasing of Hardware and Software Solutions in Health Care Systems: Potential Benefits and Perspectives
}

\author{
Ekaterina Gamova \\ Faculty of Economics \\ Volga State University of Technology \\ Yoshkar-Ola, Russia \\ eegamova@mail.ru
}

\author{
Olga Zakirova \\ Faculty of Economics \\ Volga State University of Technology \\ Yoshkar-Ola, Russia \\ myholding@mail.ru
}

\author{
Elena Rodionova \\ Faculty of Economics \\ Volga State University of Technology \\ Yoshkar-Ola, Russia \\ rodionovaev@volgatech.net
}

\begin{abstract}
The issue of leasing of hardware and software solutions in health care systems is considered in the context of the project RFMEFI577170254 "Intraoperative navigation system with support of augmented reality technology on the basis of virtual 3D models of organs obtained from CT diagnostics for minimally invasive operations", since this the project involves the introduction of hardware and software systems in the practice of medical institutions for performing organ-preserving operations and segmental resections, which provide the applying of worldclass technologies during surgical interventions. A lot of medical institutions in Russia have financial problems and are not able to purchase hardware and software systems using their own or credit funds. Thus leasing is a priority opportunity to use modern equipment in medical practice. The rationale for the research study is in the fact that limited funding is associated with the main problem of providing innovative equipment; therefore, leasing is regarded as the most economic finance instrument for purchasing medical equipment. The calculation of the efficiency of finance leasing by discounting method in comparison with other methods of financing the purchase of medical equipment was performed; the conclusion was performed on the optimality of leasing as a form of investing in the purchase of equipment and its advantages over crediting and acquisition at sole cost and expense.
\end{abstract}

Keywords: finance leasing, high-tech equipment, health care, financing of health care centers, the system of intraoperative navigation

\section{INTRODUCTION}

Today, the medical device market has taken a huge step ahead. Brand-new medical devices, specialized machinery and equipment are being developed. The medical device industry is evolving rapidly, with key technologies leading the fourth industrial revolution [1]. The scientific community offers the market specialized medical equipment and even whole complexes and systems capable of solving the tasks in the fight against different diseases.

Medical devices are important to provide health care and to improve the health of individuals and populations. This fact is recognized by World Health Organization (WHO). One of WHO's strategic objectives is to ensure improved access, quality and use of medical devices [2].

The issues of unsatisfactory, worn-out conditions of medical devices are recently being paid more attention; the Government of the Russian Federation has enshrined health care as a national priority project, consequently, it is expected that the amount of funding will increase, including the amount for acquisition and replacement of the worn-out and obsolete medical equipment.

According to TEBIZ GROUP research data, the model of medical device market in Russia is import-oriented, where the majority of medical goods is produced by foreign manufacturers. The volume of imported supplies exceeded domestic production by 2601.5 times within the structure of the medical device market in 2016. KAMPO, Elatomsky Instrument Plant, and LINZMASTER earned the most money 
on production. Most of the supplies were imported from Germany in 2016 (more than 48\%), the leading supplier of medical devices was VARIAN MEDICAL SYSTEMS PARTICLE THERAPY GMBH (8.1\%). Most of the Russian products exports are purchased by Kazakhstan (more than $40 \%$ ), the largest buyer is BVSA PTY LTD (14.1\%). Experts estimated the market of medical expendables at 1060 million dollars and it has been annually increasing by $10 \%$, thus, by the year of $201990 \%$ of the market will belong to domestic producers.

The Federal Target Program 'Development of the pharmaceutical and medical industry in the Russian Federation for the period until 2020" for 2016-2017 aims at extensive production of medical products; besides, by the year of 2018 the economic lifecycle of the medical devices purchased under the Healthcare Modernization Program for 2011-2012 will expire, so there will be a need to provide medical facilities with certain types of equipment.. In the long term until 2019, we can expect a steady growth in the private medicine market, and we can expect creation of about 3 thousand jobs. According to the expert assessment of the Industrial Partner (Mari Machine-Building Plant), the potential revenue from the production and sale of innovative products over the next 5 years will be more than 1.5 billion rubles, which will ensure the volume of tax revenues to budgets of all levels in the amount of more than 300 million rubles.

In this regard, there is a need to create software and hardware systems for modeling segments of human organs to perform preserving surgery and segmental resections, ensuring implementation of world-class technologies in surgical procedures [3].

Such equipment is essential to replace imports in the field of software and hardware systems for medical purposes, designed to inform a surgeon who prepares and conducts minimally invasive operations, and to ensure export potential by conducting a competitive pricing policy for the promotion of developed complexes in foreign markets.

The purchase of such systems for health care centers will improve the efficiency of the use of in-use medical tomographic equipment and equipment for laparoscopic operations by providing additional analysis and data processing capabilities at both preoperative and operative stages [4].

This will ultimately lead to progressive structural changes in medical practice by expanding the range of surgeons who use minimally invasive surgery technologies, creating new jobs by organizing the production of software and hardware systems, and introducing specialists in the information support of minimally invasive surgical interventions [5].

The competitive advantages of the equipment consist in the possibility of creating a low-budget software and hardware system that reduces the number of operational and postoperative complications, reduces the time of operations, shortens the rehabilitation period, improves the cosmetic effect, despite the status of a health care center and experience of practicing specialists. These systems can be used in regional, city, provincial-level, and federal health care centers

The work was financially supported by the Ministry of education and science of the Russian Federation, the project RFMEFI577170254 "Intraoperative navigation system with support of augmented reality technology on the basis of virtual 3D models of organs obtained from CT diagnostics for minimally invasive operations" of the Russian Federation, that practice technologies of minimally invasive surgical interventions [6].

The only issue in implementing this idea may become problems associated with financing the purchase of these systems for hospitals. Therefore, it is essential to consider the optimal and effective options for acquiring this equipment. Financial leasing can be considered the most financially justifiable way of investing in the acquisition of high-tech medical equipment, which is more economically beneficial for medical institutions - the lessees, in terms of costs and taxes in comparison with lending and purchasing such systems at sole expense.

The problem of updating medical equipment, including leasing mechanism, has been widely debated in state authorities, scientific community, society, and media. Such authors as Yu.S.Kudryavtsev, O.L.Filonova, V.Ya.Zinichenko, S.V.Novikov, A.V.Bogoviz, I.V. Dolgov and others made a significant contribution to solve the issue. Common questions of theory, essence and types of leasing are considered, in particular, in the works by V. Gazman, V. Goremykin, V. Joukh, A. Yu. Martynov, A. Movsesyan, D. A. Surgutov. The role of leasing in the investment process is discussed in the works by G. Birman, S. Katyrin, P. Vilensky, V. Livshits, S. Smyak, S. Mikhailova, R. Suyumbaeva, A. Pervyshina, and many others. These studies see the problems of leasing as part of common problems of investment, development of lease relations and the legal aspects of leasing activity from the point of view of using leasing in the practice of economic activity and the benefits that parties gain. The development of international leasing is debated in the works by L. Prilutsky, A. Yusupov.

The financial and economic aspect of the leasing deal is best described in the scholastic papers, that address the problems of investment and leasing, and include such names as V.D. Gazman, V.A. Goremykina, T.A. Kraseva, M.I. Leshchenko and others.

Financial leasing has been the subject of research of such scholars as: V. Anson, P. Balthus, E. Griswold, H. Kötz and K. Zweigert, H. Koch, L. Lacour, H.J Lask, G. Magnus, A. Pollard, L. Friedman, C.Schmitthoff, H.-J. Spitler et al.

Russian legal and economic literature evaluates in a different way the circumstances associated with leasing agreements. According to legal experts, leasing first emerged in the US in the middle of the 19th century, and in other countries of the West it has become widely used since the middle of the 20 th century as a legal institution established to regulate new forms of investing money in the economy associated with the use of such a method as acquisition by financial organizations at the request of industrial enterprises of machinery and equipment, and then transfer the equipment to those enterprises for rent [7].

So, M.I. Kulagin, describing the changes that has recently occurred (since the beginning of the 1980-s) in the system of agreements in the Western countries, noted that 'Since the middle of this century, leasing contracts, especially for leasing machines and equipment, have become very popular. Due to the leasing agreement, one party (the leasing company) 
transfers to the other party (the user) a certain object (car, vehicle, enterprise, etc.), and the user undertakes to pay for it a fee and upon termination of the contract has the right to purchase the named object on preferential conditions, with offset of these payments. The contract of leasing combines the characteristics of both contracts for lease of property (rent), and the contract of sale' [8].

Similar views were held by Yu.I. Svyados, who wrote: 'Relations on the use of machine and technical products in national and international economic circulation are increasingly based on a specific contractual form of property hiring, which has been called the contract of leasing. Initially originated in the US in the middle of the last century, since the late 50's, this type of contract has been widely used in business practice by firms in Western Europe and Japan, and is currently being used in almost all countries. Leasing has become legal in many countries that do not have special legislative regulation (USA, West Germany, Japan, etc.), but in some countries special regulatory acts on leasing relations have been published (France - Act of 2 July 1966, England Law on the rental and sale of 1965)' [9].

Scholars of the history of leasing development in Western countries usually point out that the development of railway transport served as an impetus to the wide use of leasing in the United States and Western Europe: railway companies, trying to avoid unnecessarily burdensome expenses, sought to acquire locomotives, wagons and other vehicles not by right of ownership (contracts of purchase and sale), but only for use. For this purpose, at the initial stage in the United States, the structure of the trust was applied, when trust companies acquired the appropriate vehicles and subsequently transferred them to the use of railway companies [10]. Later interests of companies - manufacturers of vehicles in selling their products on the one hand, and financial companies interests in a profitable investment of capital on the other hand led to a change in the investment system: financial companies began to purchase vehicles and other equipment that the transport companies needed from a certain manufacturer at the request of operating organizations, and further transferred the equipment for rent. In the early 50 -s of the 21 st century in the United States, the leasing of technological equipment, machinery, ships, aircraft, etc., to the operating organizations, became widespread. The same year the first specialized leasing companies emerged. Commercial banks of the USA began to take part in leasing operations, who obtained official permission from the US Federal Reserve to create subsidiaries for leasing operations. Similar processes emerged in Western Europe and Japan [11].

Despite the existing differences in the terminology and elements that make up the content of agreements regulating leasing relations, it is still a question of one and the same contract. E.V. Kabatova cites the definition of the leasing agreement given in one of the documents of the European Association of National Leasing Companies (Leaseurope): 'Leasing is a lease contract for an enterprise, industrial goods, equipment, real estate for use by the lessee for production purposes, while goods are bought by the lease provider and the latter retains the right of ownership' [12].
Thus, leasing of key assets, which includes any medical equipment, is one of the modern, progressive and effective forms of investing in the purchase of new equipment and hightech medical systems, especially under the conditions of limited financing, which has evident economic, financial and tax benefits for the lessee - a health care center of any form of ownership. WHO claims that the option of leasing equipment can be attractive when compared to the high capital cost of some items, and it gives the vendor an incentive to keep equipment operational [13].

However, the medical equipment leasing can be a complicated process and efficiency of invested financial resources in modernizing medical equipment will be estimated to a greater extent not by their volumes, but by the rationality and optimality of their investments, which requires a quantitative and qualitative analysis of the availability of medical equipment and the condition of the medical equipment used in health care centers $[14,15]$.

\section{FinANCIAL ASPECTS OF HEAlth CARE AND FUNCTIONING OF THE MEDICAL DEVICE MARKET}

Russian program 'Health care Modernization' has been put into action, and this includes, among other things, the modernization of high-tech medicine. There is a large volume of purchases of high-tech medical devices. Nevertheless, even allocated volumes of budgetary and non-budgetary financing for the acquisition of medical equipment are not enough to replace worn-out equipment of medical institutions with hightech medical equipment. In such a case, it is necessary to use debt funds [16].

Public expenditures on health care in Russia in relation to GDP is 3 times lower than that of the leading European countries. The USA, the leader in private health care insurance, spend $17.6 \%$ of their GDP on health care. Countries with the highest levels of health care expenditures per capita are mainly countries in the USA and European regions of WHO. It is not surprising that during the last 10 years we can observe the emergence of a large number of private medical centers and clinics that replace the public sector with medical service. In recent 6 years there has been a steady increase in the market for paid medical services. Since 2002 the market for private medical services has become 4 times bigger. The growth rate of the paid medical services market is more than $20 \%$ per year. The volume of the medical market in Russia in 2017 exceeded 2.2 trillion rubles and the segment of private medicine grew faster compared to other segments. Because of the reduced financing and quality of services in the public sector, private clinics are enjoying their 'golden years' - the growing demand allows them to earn more, reinvest their profits in new lines and open new branches, and acquire new modern high-tech medical equipment [17].

Medicine is a highly competitive sphere, the success of which is possible only if the centers and clinics are equipped with up-to-date medical devices. The use of modern medical equipment contributes to increasing the accuracy of diagnosis, improving the recovery rates of patients, and providing positive feedback on the activities of the clinic [18]. 
Let us consider the financial aspects of the issue under study on the example of one of the territorial entities of the Russian Federation - the Republic of Mari El (RME).

Financing of medical institutions of the Republic of Mari El comes from the regional budget of the Republic of Mari El under the classification of expenditures 09 'Healthcare'. Thus, in 2018, 3.0\% of all budget expenditures or 805.044 million rubles were allocated from the consolidated health budget of the RME, while $3.58 \%$ or 804.537 million rubles were allocated to health care for the republican budget of the RME in 2018.

In the medium-term period, health expenditure is envisaged in the medium-term planned republican budget of the RME until 2020 in the following amounts: in $2018-804.5$ million rubles, in 2019 - 800.3 million rubles, and in 2020 800.3 million rubles.

The governmental order of the RME from 10 August, 2017 No353-r approved a list of State programs in 26 lines, including the program "New Quality of Life", which involves the development of health in the region, along with the other 15 areas of this program. As specified in budget allocations for the state programs up to $2020,847.9$ million rubles have been allocated for the subprogram "Development of Healthcare of the Republic of Mari El" in 2018, with a share of program costs in the total expenditure of 4.3\%; in 2019 - 845.9 million rubles and $4.7 \%$; in $2020-845.9$ million rubles and $4.8 \%$ respectively. Within the program there are two lines, namely, "Improvement of high-tech medical care, the development of new effective methods of treatment" and "Provision of specialized medical aid in the framework of high-tech medical care" that are being implemented, in 2017 eight medical institutions of the Republic of Mari El were provided with high-tech medical assistance, with the financial support of 657.574 thousand rubles.

The financial resources allocated to the Ministry of Healthcare of the Republic of Mari El do not correspond to the needs of the industry, but are defined only by the economic opportunity of the country. Nevertheless, the available funds should be spent rationally. However, the situation with the provision of medical institutions with medical devices is hard to manage. Although for the first time in 2017 the total wear of the equipment for the year did not increase, but decreased by $3 \%$, its wear is still $85 \%$.

\section{LEASING AS A FINANCIAL TOOL FOR UPDATING MEDICAL EQUIPMENT}

It is not rare that both public and private medical institutions have the resources, sufficient for the purchase of expensive equipment. Leasing, as well as the rent of medical equipment, makes it possible to modernize the equipment of medical institutions without large single costs [19]. In such a manner can be purchased hardware-software solutions, endoscopic and cardiological equipment, equipment for cosmetology, physiotherapy, dentistry, etc. As a result of the conclusion of the leasing agreement, the specialists of the medical institution are able to access the latest technologies, there is an opportunity to improve the quality of care provided to patients. At the same time, the cost of equipment is paid step-by-step - in fact, the rent equipment make it possible not only to recoup itself, but also to bring profit.

Modern and high-tech medical equipment is necessary for effective work of doctors of any specialization. Often the accuracy of the diagnosis, the quality and speed of the manipulations performed, or the period of rehabilitation of the patient depend on the quality of the equipment. In addition, the employees of the medical institution are highly interested in equipping the medical offices at the highest level.. Hightech medical equipment provides innovative opportunities: new drugs and technologies increase the number of diagnoses that can be treated, shift diagnostics to earlier periods, reduce the impact of therapy on the body, and ultimately expand the range of potential patients. Artificial intelligence already helps to monitor, identify and prevent diseases in the early stages. Apart from diagnostics, preventive and anti-aging medicine, 3D printing technologies of implants and organs are being developed. Online consultations, which help expand the client audience are being introduced along with technological solutions.

Leasing of medical equipment is a financial instrument that allows any medical institution to significantly increase the level of technical equipment with minimal costs [20].

Compared to the alternative methods of crediting, leasing of medical equipment looks like the most convenient and economical tool for technical modernization of medical institutions. It differs favorably from bank loans that are inaccessible to most health care centers and are not very practical in terms of taxation.

Leasing of medical equipment is considered a highly demanded service, in view of the large number of benefits it provides to medical institutions. First, there is a program of subsidizing medical institutions in Russia. The funds received under this program can be immediately used as an advance payment. Secondly, medical equipment under the leasing agreement is characterized by a high level of liquidity. Thirdly, this service does not provide for additional security, since the medical equipment itself is the security [21]. Other advantages of the leasing deal include the following:

- no need in a document flow with the supplier and the insurance company;

- the property is on the central asset register of the lessor, therefore the medical institution has the opportunity to receive additional loans;

- purchase of leasing medical equipment does not affect the credit history of the lessee;

- no need to make lump-sum cash investment;

- flexible schedule of leasing payments;

- referring all leasing payments to cost value;

- legal reduction of the tax assessment base.

The leasing market for medical equipment is wide enough. A dozen of leasing companies provide leasing services for medical equipment: "Leasing-Medicine", a company that specializes primarily in leasing medical equipment; leasing 
scheme is allowed to the participants in the leasing agreement with an increase coefficient of not more than 3 .

The remuneration to the lessor is calculated for the first and second years by different formulas [23]:

For the first year:

$$
r=B V \times(4 \% / 12) / 100 \%
$$

where, $r$ - is the remuneration to the lessor; $B V$ - is a book value of equipment.

For the second year:

$$
r=A A C(p y) \times(4 \% / 12) / 100 \%
$$
calculation of the costs of the deal for the purchase of this system in three ways: at sole cost and expense, on account of the loan and on account of the lease. The initial data for the calculations are given in Table I.

\begin{tabular}{|c|c|}
\hline Indicator & Amount \\
\hline \multicolumn{2}{|l|}{ 1. Purchase price, rub. } \\
\hline 1.1. VAT included & 2000000.00 \\
\hline 1.2. VAT excluded & 1694915.25 \\
\hline $\begin{array}{l}\text { 2. Balance sheet value at the beginning of the leasing } \\
\text { deal, rub. }\end{array}$ & 1694915.25 \\
\hline 3. VAT & 305084.75 \\
\hline 4.1. Advance (VAT included), rub. & 600000.00 \\
\hline 4.2. Advance (VAT excluded), rub. & 508474.58 \\
\hline 5. Total credit, rub. & 1400000.00 \\
\hline 6. \% interest rate & 14 \\
\hline 7. Lease agreement term and credit contract, mo. & 24 \\
\hline 8. Remuneration to the lesser, $\%$ & 4 \\
\hline 9. Duration of complete depreciation, mo. & 72 \\
\hline 10. Acceleration factor & 3 \\
\hline 11. Depreciation amount per month, rub. & 70621.47 \\
\hline $\begin{array}{l}\text { 12. Total depreciation amount in a span of leasing deal, } \\
\text { rub. }\end{array}$ & 1694915.25 \\
\hline 13. Remaining value, rub. & 0.00 \\
\hline 14. Cash surrender value, VAT included, rub. & 0.00 \\
\hline Source: authors' calculations & \\
\hline
\end{tabular}

TABLE I. INITIAL DATA FOR CALCULATION

The calculation of the components of the lease payment is based on the fact that payments are made monthly. At the beginning of the contract term, an advance payment of $30 \%$ of the value of the leased asset is made against the write-off of a part of the leasing payments. A scheme for accounting for leased property on the balance sheet of the lessor was proposed [22].

The amount of annual depreciation is calculated by the formula that takes into account the coefficient of accelerated depreciation equal to 3 , since this depreciation calculation where, $r$ - is the remuneration to the lessor; $A A C(p y)$ - is the average annual cost of equipment (for the previous year).

The average annual cost of equipment is calculated by:

$$
r=\left(0,5 \times O_{e 1}+O_{e 2}+\ldots+O_{e 11}+0,5 \times O_{e 12}\right) / 12,
$$

where $A A C$ is the average annual cost of equipment; $O_{e 1}$ is the cost of equipment for the first month; $\mathrm{O}_{e 2}$ - is the cost of equipment for the second month and further, respectively.

The current payment without VAT is obtained by adding up the amount of depreciation, interest paid, property tax and compensation.

The advance payment is calculated monthly by:

$$
A_{i}=A w V A T \times C P_{i} / A C P
$$

where $A_{i}-$ is the advance payment of the corresponding month; $A w V A T$ - is the advance payment without VAT; $C P_{i}$ - is the current payment of the corresponding month; $A C P$ - is the amount of current payments.

Driven by the calculations performed, we can conclude that the amount of current payments with VAT on leasing is less than the cost of purchasing the equipment by more than 100 thousand rubles. This is because of the use of the mechanism of accelerated depreciation, which allowed to reduce the remaining value of equipment at the close of the leasing contract. The latter helped reduce the property tax and the amount of compensation to the lesser [24]. 
TABLE II. COMPARATIVE CALCULATION OF THE USE OF OWN RESOURCES, CREDIT RESOURCES AND LEASING WHILE PURCHASING MEDICAL DEVICES, THOU.RUB.

\begin{tabular}{|c|c|c|c|}
\hline \multirow[b]{2}{*}{ Indicator } & \multicolumn{3}{|c|}{ Form of investment } \\
\hline & Credit & $\begin{array}{c}\text { Own } \\
\text { resources }\end{array}$ & Leasing \\
\hline $\begin{array}{l}\text { Payment for shipment } \\
\text { (VAT included) }\end{array}$ & -2000000 & -2000000 & -600000 \\
\hline Receipt of a credit & 1400000 & 0 & 0 \\
\hline Repayment of a credit & -1400000 & 0 & 0 \\
\hline $\begin{array}{l}\text { Credit interest (one } \\
\text { year credit) }\end{array}$ & -106166.666 & 0 & 0 \\
\hline $\begin{array}{l}\text { Savings on income tax } \\
\text { owing to interest on } \\
\text { the credit }\end{array}$ & 25480 & 0 & 0 \\
\hline $\begin{array}{l}\text { Savings on income tax } \\
\text { owing to depreciation }\end{array}$ & 406779.662 & 406779.662 & 0 \\
\hline Property tax & -111864.406 & -111864.406 & 0 \\
\hline $\begin{array}{l}\text { Savings on income tax } \\
\text { owing to property tax }\end{array}$ & 26847.458 & 26847.458 & 0 \\
\hline $\begin{array}{l}\text { Lease payment (VAT } \\
\text { included) }\end{array}$ & 0 & 0 & -1790500 \\
\hline Savings on VAT & 305084.746 & 305084.746 & 364652.542 \\
\hline $\begin{array}{l}\text { Savings on income tax } \\
\text { for leasing }\end{array}$ & 0 & 0 & 486203.39 \\
\hline Total & -453839.209 & -373152.542 & -539644.068 \\
\hline
\end{tabular}

Table II presents the results of comparison of calculation of expenses of medical institution on acquisition of the medical equipment at sole cost and expense, on account of the loan and on account of the lease.

Analysis of Table II shows that leasing can look less beneficial at first sight. However, it is essential to make an amendment to the time factor, that is, to apply the method of discounting payments.

The average monthly rate of inflation, which is $1.17 \%$, should be used as the discount rate.

The calculation should take into account the frequency of payment of income tax, property tax, as well as VAT when calculating the discounted value of property tax, savings on income tax due to depreciation, interest on the loan, property tax, leasing payments, and savings on VAT [25].

While the authors were drafting the paper, the calculations were made of savings in income tax and VAT at the expense of different resources, taking into account the time factor.

The following formula is applied to calculate the discount coefficients:

$$
D C=1 /(1+i)^{n},
$$

where, $D C$ - is the discount coefficient; $i$ - is the average monthly inflation rate $(1,17 \%) ; n-$ is the serial number of the corrsponding time period.

As a result, once again reducing all payments and savings, we obtain a comparative calculation of the use of different forms of investment, taking into account discounting. It is presented in Table III.

TABLE III. COMPARATIVE CALCULATION OF VARIOUS FORMS OF INVESTMENTS WITH THE USE OF DISCOUNTING METHOD, THOU.RUB.

\begin{tabular}{|c|c|c|c|}
\hline \multirow[b]{2}{*}{ Indicator } & \multicolumn{3}{|c|}{ Form of investment } \\
\hline & Credit & $\begin{array}{c}\text { Own } \\
\text { resources }\end{array}$ & Leasing \\
\hline $\begin{array}{l}\text { Payment for shipment } \\
\text { (VAT included) }\end{array}$ & -2000000 & -2000000 & -600000 \\
\hline Receipt of a credit & 1400000 & 0 & 0 \\
\hline Repayment of a credit & -1299097.44 & 0 & 0 \\
\hline $\begin{array}{l}\text { Credit interest (one year } \\
\text { credit) }\end{array}$ & -100615.08 & 0 & 0 \\
\hline $\begin{array}{l}\text { Savings on income tax } \\
\text { owing to interest on the } \\
\text { credit }\end{array}$ & 23524.96 & 0 & 0 \\
\hline $\begin{array}{l}\text { Savings on income tax } \\
\text { owing to depreciation }\end{array}$ & 266127.68 & 266127.68 & 0 \\
\hline Property tax & -83317.06 & -83317.06 & 0 \\
\hline $\begin{array}{l}\text { Savings on income tax } \\
\text { owing to property tax }\end{array}$ & 19996.1 & 19996.1 & 0 \\
\hline $\begin{array}{l}\text { Lease payment (VAT } \\
\text { included) }\end{array}$ & 0 & 0 & -1553225.04 \\
\hline Savings on VAT & 299807.76 & 299807.76 & 314494.78 \\
\hline $\begin{array}{l}\text { Savings on income tax } \\
\text { for leasing }\end{array}$ & 0 & 0 & 409808.42 \\
\hline Total & -473573.092 & -497385.526 & -428921.843 \\
\hline
\end{tabular}

Analysis of Table III allows us to conclude that for a lessee, leasing is the most profitable form of investing funds to purchase this equipment. Calculations showed that leasing with the factor of time is cheaper than other sources of financing.

As you know, the main advantage of leasing is the possibility of deducting VAT from the tax assessment base for this tax. This advantage was not applicable to health care centers, due to the fact that they are not payers of this tax. However, from 1 October, 2017 leasing of medical equipment is not subject to VAT. That will make leasing deals for medical institutions as profitable as for other types of business entities.

When medical centers lease medical devices, VAT is not added to the cost, the initial cost of equipment is not increased by $18 \%$, consequently, those health care center enjoy lower leasing interest.

Based on the above calculations, we can conclude that the use of such a form of financing as leasing for the acquisition of new types of equipment and medical devised is advantageous, since the following benefits of the leasing deals become obvious:

- leasing operations do not require the immediate withdrawal of budgetary funds of the organization to pay for the required but rather expensive property, and do not require instant payments;

- taking into account the fact that the property, while being the subject of the leasing agreement, also represents a security 


\section{ACKNOWLEDGMENT}

under this agreement, this method is considered much simpler and safer than getting credit funds for acquisition;

- the terms of leasing agreements are established by the parties, and this allows finding a general consensus beneficial for each of the participants, thus making the system flexible and profitable;

- this type of operations allows for a variety of types of security;

- contracts of this form eliminate various risks that are inevitably associated with personal ownership of property;

- for the lessee, all costs under the current leasing agreement, from the point of view of tax structures, are totally related to the production costs in their full amount, and therefore are not considered as profit in taxation;

- acquired by the lessor medical equipment will also not be taxed, since in fact it is not listed on its balance sheet;

- leasing provides skilled technical support and service maintenance.

\section{CONCLUSIONS}

Russia's priority goal is to build an advanced healthcare system, as well as develop and implement the latest methods of diagnosis and treatment of diseases.

Thus, the purchase of innovative medical equipment becomes priority forl health care centers. Since intraoperative navigation systems supporting the technology of augmented reality based on virtual 3D models of organs are essential for minimally invasive operations, the researches on this issue are important for the development of Russia's medicine and public health care.

The economic effect of the implementation of the hardware and software systems is stipulated by a reduction in the costs of operations and rehabilitation; an opportunity to release new products on the basis of the industrial partner; improvement of the quality of medical services; improvement of the technology of minimally invasive operations; increase of the level of automation in preparation for operations. The social effect of the introduction of innovative medical equipment is in reducing the losses from socially significant diseases and the death rate among working age adults. Preventing diseases in the early stages, modern and nonsurgical treatment of serious and dangerous diseases - these are issues that require immediate solutions and funding.

The data given in the article proves that leasing is by far the most effective option for financing health care centers and let them purchase high-tech medical devices. The recent changes in the tax legislation in relation to VAT made leasing for health care centers even more profitable. The opportunity to get subsidized part of the costs incurred to purchase medical equipment through leasing makes this financial instrument the best option.
Authors thank the anonymous peer reviewers for their insightful comments and suggestions.

\section{REFERENCES}

[1] M. Lee, "Strategies for promoting the medical device industry in Korea: an analytical hierarchy process analysis", in International Journal of Environmental Research an Public Health, 2018, vol. 15, 2569 p.

[2] "Medical devices: managing the mismatch: an outcome of the priority medical devices project 2010", World Health Organization [Electronic resource]. Available at http://apps.who.int/medicinedocs/documents/s17704en/s17704en.pdf [Accessed: 10 September 2019].

[3] J. K. C. Lee, R. B. W.Tan, and E. Chung, "Erectile dysfunction treatment and traditional medicine-can east and west medicine coexist", in Translational Andrology and Urology, 2017, vol. 6, no. 1, pp. 91-100.

[4] T. Basché, "Imaging and force transduction in correlative scanning force and confocal fluorescence microscopy", in EPJ Web of Conferences, 2018, vol. 190, 02002 p.

[5] Y. S. Kudryavtsev and O. L. Filonova, "Problems of technical equipping of health care centers and possible solutions", Problemi tekhnicheskogo osnascheniya uchrezhdenii zdravokhraneniya i vozmozhnie puti ikh resheniya, in Healtcare manager, Menedger zdravokhraneniya, 2007, vol. 8, pp. 51-59.

[6] P. Slaby, P. Bartos, J. Karas, R. Netusil, K. Tomanova, and M. Vacha, "Phow swift is cry-mediated magnetoreception conditioning in an american cockroach shows sub-second response", in Frontiers in Behavioral Neuroscience, 2018, vol. 12, p. 107.

[7] S. Inoue, S. Hirata, S. Yamamoto, M. Ringhofer, R. S. Mendonça, and C. Pereira, "Spatial positioning of individuals in a group of feral horses: a case study using drone technology", in Mammal Research, 2019, vol. 64, no.2, pp. 249-259.

[8] M. I. Kulagin, "Selected works on corparate and commercial law", Izbrannie trudi po aktsionernomu i torgovomu pravu, 2nd ed, Moscow, Statut, 2004.

[9] E. A. Vasiliyev, V. V. Zaitseva, R. L. Naryshkina, and Y. I. Svyadosts, "Civil and commercial law of capitalist states", Grazhdanskoe i torgovoe pravo kapitalisticheskih gosudarstv, Moscow: International relations, 1983.

[10] D. Bialuschewski, R. Frohnhoven, M. Deo, Y. Gönüllü, T. Fischer, S. Mathur, J.S. Hoppius, and E.L. Gurevich, "Laser-textured metal substrates as photoanodes for enhanced pec water splitting reactions", in Advanced Engineering Materials, 2018, vol. 20, no. 9, 800167 p.

[11] E. A. Vasiliyev, "Grazhdanskoe i torgovoe pravo zarubezhnikh gosudarstv", Civil and commercial law of Foreign States, Moscow: International relations, 2008.

[12] E. V. Kabatova, "Leasing: legal regulations, practice", Lising: pravovoe regulirovanie, praktika, Moscow: INFRA-M, 1998.

[13] "Procurement process resource guide 2011" [Electronic resource]. Available https://apps.who.int/medicinedocs/documents/s21563en/s21563en.pdf [Accessed: 10 September 2019].

[14] Y. S. Kudryavtsev, V. Y. Zinichenko, S. V. Novikov, and O. L. Filonova, "Medical and technical support of the health care system problems and solutions", Mediko-tekhnicheskoe obespechenie sistemi zdravookhraneniya - problemi i puti resheniya, in Healtcare manager, Menedger zdravokhraneniya, 2007, vol. 12, pp. 34-42.

[15] V. Sharp, and K.J. Kreder, "Medical equipment: leasing vs. buying", in The Complete Business Guide for a Successful Medical Practice, 2015, pp.133-148.

[16] A. V. Shulaev, M. P. Mazitov, and M. R. Gataullin, "Clinical and economic efficiency of the use of medical equipment in municipal health facilities of a metrapolis", Kliniko-ekonomicheskaya effektivnost ispolzovaniya meditsinskogo oborudovaniya $\mathrm{v}$ munitsipalnikh uchrezhdeniyakh zdravookhraneniya megapolisa, in Saratov Journal of 
tax preferences", Lising kak instrument finansirovaniya innovatsionogo

Medical Scientific Research, Saratovski nauchno-meditsinski zhurnal, 2011, vol. 4, pp. 779-783.

[17] R. H. Blick, H. Graener, A. Mews, H. Weller, R. Wiesendanger, and W. J. Parak, "Nanoscience and nanotechnology at the centennial of universität hamburg", in ACS Nano, 2019, vol. 13, no. 1, pp. 1-3.

[18] E. H. Morreim, "A dose of our own medicine: alternative medicine, conventional medicine, and the standards of science", in Journal of Law, Medicine and Ethics, 2018, vol. 31, no. 2, 222 p.

[19] D. K. Yandavletova, "Benefits of leasing for the state", Preimuschestva lisinga dlya gosudarstva, in International research journal, Mezhdunarodnii nauchno-issledovatelski zhurnal, 2013, vol. 10-3 (17), pp. 96-97.

[20] L. Z. Buranbaeva, and D. K. Yandavletova, "Leasing in the health care system: current state, problems, and tendencies", Lising v sisteme zdravookhraneniya: sostoyanie, problemi i tendentsii, in Problems of modern economics, Problemi sovremennoi ekonomiki, 2015, vol. 1 (53), pp. 296-299.

[21] P. N. Mashegov, and A. A. Belski, "Leasing as a tool for financing innovative development and the issue of assessing the effectiveness of razvitiya $\mathrm{i}$ problema otsenki effektivnosti nalogovikh preferentsii, in Finances and credit, Finansi i kredit, 2013, vol. 45 (573), pp. 10-18.

[22] B. Walder, and M.R. Tramer, "Evidence-based medicine and systematic reviews in perioperative medicine", in Der Anaesthesist, 2015, vol. 50, no. 9.

[23] M. von Wolff, P. Stute, and B. Mosimann, "New aspects of practical relevance in gynecological endocrinology, reproductive medicine, and prenatal medicine-part 1: reproductive medicine and prenatal medicine", in Gynäkologische Endokrinologie, 2019, vol. 17, no. 2, pp. 117-122.

[24] K. K. Boyer, and P. Pronovost, "What medicine can teach operations: what operations can teach medicine", in Journal of Operations Management, 2010, vol. 28, no. 5, pp. 367-371.

[25] M. Bochud, I. Guessous, and M. Burnier, "Top three pharmacogenomics and personalized medicine applications at the nexus of renal pathophysiology and cardiovascular medicine", in Current Pharmacogenomics and Personalized Medicine, 2011, vol. 9, no. 4, pp. 299-322. 